\title{
A SHORT ANALYSIS OF QUALITY AND PERFORMANCE IN THE RADIO SEGMENT OF ROMANIAN MASS-MEDIA
}

\author{
Daniel Burtic \\ RVE, Oradea, Romania \\ rve.daniel@gmail.com
}

\begin{abstract}
More than one hundred years ago, once the radio appeared, mass media started to be more pronounced. Mass-media market diversified its offer, and the quality and creativity of economical agents determined a reassert on the competition and performance scale. For our research in mass media field, we distinguish two vital aspects of economic quality and performance: audience and financial results. In this section we will try to follow the evolution of the main players from the Romanian audio-visual market on the radio segment, taking into account these two variables: audience and financial results. Quality and performance in mass-media are two elements desired on one side by massmedia producers: the owners and employees from this field, and on the other side, by mass-media customers: audience and publicity buyers. We analyse the aspects of quality and performance in Romanian media industry in o period of rapid change. The changes are on multiple levels, and the most accentuated regards the consumer's behaviour, market environment, technological changes and legal regulations. The changes in the consumer behaviour are determined by their perceptiveness towards the digital world. Quality and performance in mass-media are two desired elements, on one side by the mass-media producers: owners and employees in the field, and on the other side by massmedia customers: audience and publicity buyers.
\end{abstract}

Keywords: communication; mass communication; mass media; media economics; creative economy.

JEL classification: L82; D83.

\section{Introduction}

As a communication tool, radio made it possible to transmit immediate information, with accuracy and professionalism. There have been periods in the history of radio (just as we showed in the first chapter of our research) when this communication instrument had a central role in media industry. Today, although time has brought other actors that hold bigger segments in mass-media, radio still has many friends; although in the present radio isn't in its most favourable period, being popular and of interest for the listeners, an important mass of people listen daily to different radio stations.

Methodologically, we begin by observing the current situation in mass-media industry and economy and we propose to make an analysis of content. We will talk about aspects that aim the challenges and opportunities in media industry in the digital context, analysing the opinions of other researchers about these subjects. We are trying to present the concepts we sustain in the light of other important paper works and to exemplify them with realities from the Romanian mass-media economy. 


\section{Predispositions of the radio segment part of Romanian mass-media market}

Economical operators that activate on this specific market in Romania have plenty of challenges and opportunities in order to give value to the potential of this resource and to make performance, step by step rising up the quality standard. Quality and performance are not negotiable but it is achieved step by step by "dividing the vital elements from the banal ones" (Juran, 2011: 31). In order to make the division Juran is talking about, we must study the consumer behaviour which has a permanent dynamic, the thing that doesn't change in this behaviour being exactly the changing character. We find in the audio-visual market the alternations appeared in the consume preferences on different markets. Among the factors of alternations that influence radio audience, the most important are: place where people listen to radio, the type of device and the time in the day radio programs are listened to. We watched in the past five years the variations of radio consumption taking into account the place these services are accessed and we will try to present these trends in the next graphic.

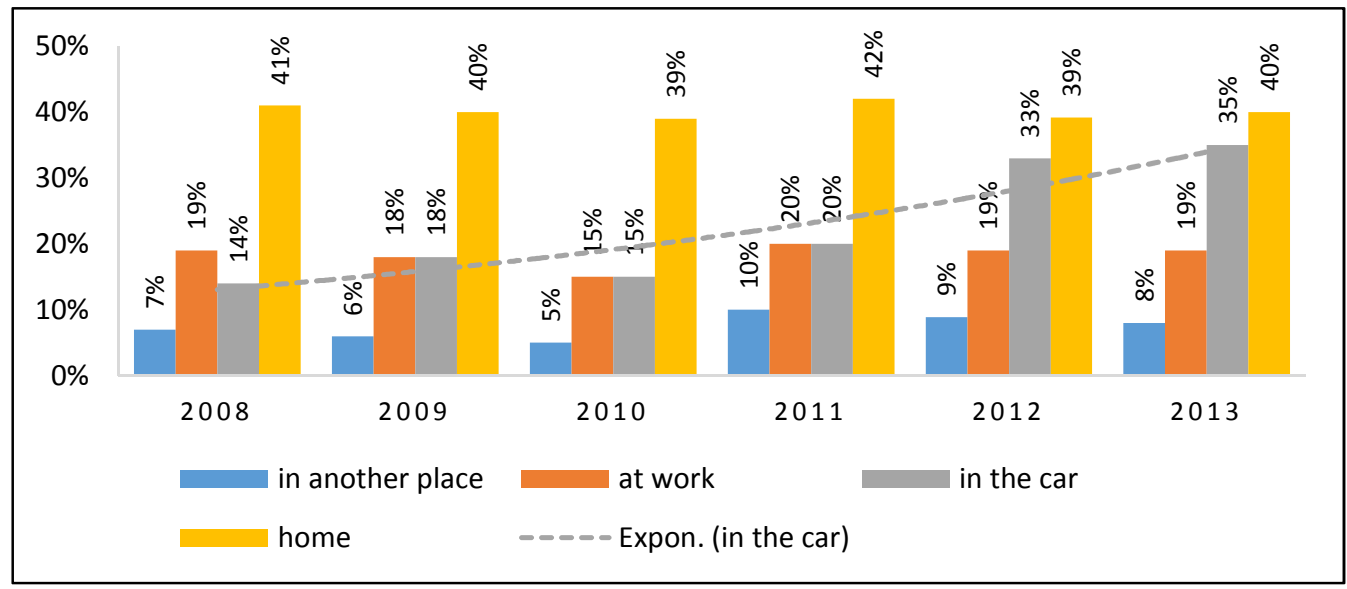

Figure 1: Evolution of radio audience (\%) in the period 2008-2013 according to the place radio is listened to.

Source: Designed by author based on the data provided by Media Factbook available on site: www.mediafactbook.ro/ accessed in the $30^{\text {th }}$ of October 2015.

As we can notice in this graphic, radio audience - although it had an decreasing fluctuation between 2008-2010 - after this period it recorded a fast recover witch has continued between 2013-2013 having a constant growth. This fact was determined by audience growth in the car. The fact that people spend more and more time in traffic, in conjunction with adapting radio programs to the demand of listeners (meaning an increase in the quality of radio programs) it seems to have brought an increase of interest towards radio programs. About $70 \%$ of the Romanian people consume radio programs. We can notice that the interest of consumers remains to a high level; this is why we tried to discover the communication channel these services are accessed through. In the next two graphics we present a pronounced analysis of the sources type through what radio content is received and the place of the reception. 


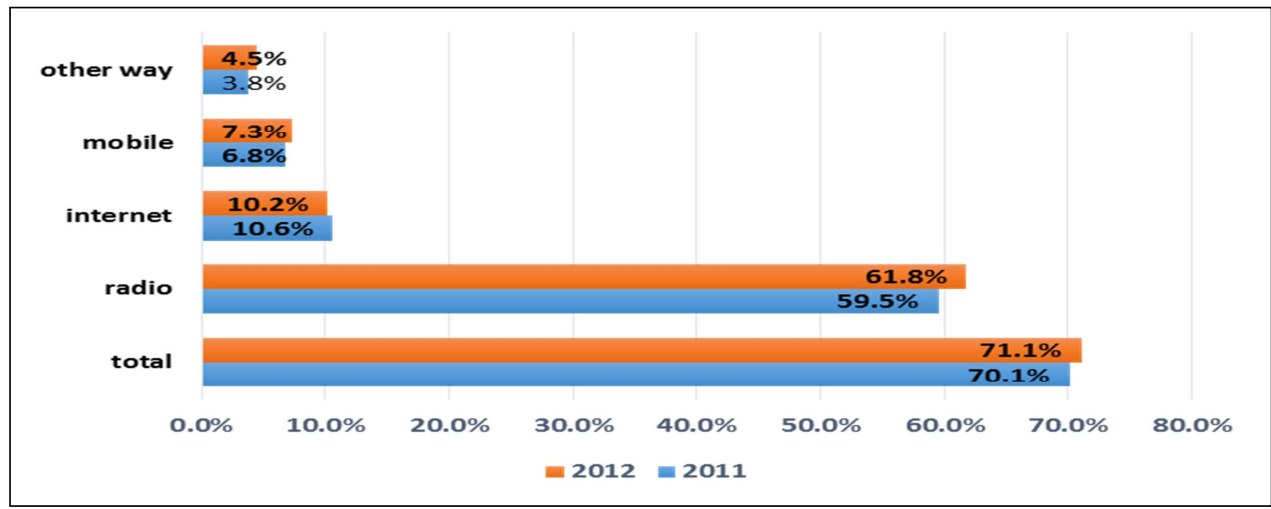

Figure 2: Situation (\%) of radio audience according to the way radio stations are received in Romanian towns, through the week (Monday to Friday) - comparing 2011-2012.

Source: Designed by author based on the data provided by Media Factbook 2013 available on site: www.mediafactbook.ro/ accessed on $10^{\text {th }}$ of Jan 2016.

First of all we can notice a $1 \%$ growth of total radio audience in 2011-2012, which means that we have a positive trend maintained to high rate of interest, around $70 \%$.

Secondly, although Romanians access more and more internet services, it seems that radio programs are accessed in a smaller rate through the internet and we can determine in this segment a drop in the period 2011-2012.

Thirdly, we can say that the data provided by The Society of Radio Audience present us something else than we expected because the main reception way is through radio devices. Moreover, in the analysed period we have in this segment a $2.3 \%$ growth, from $59.5 \%$ to $61.8 \%$.

Fourthly, we can notice a growth of radio audience on the cell-phone from $6.8 \%$ to $7.3 \%$. It seems that fix or mobile internet has a smaller influence on radio audience than on other mass-media sectors. In the same time, our research leads us to the idea that in Romania the radio remains, at least on a short and medium term, a sector with economic potential that doesn't drop but is has a small growth.

\section{Elements of economic performance quantified in radio audience numbers}

Quality and performance in mass-media are two desired elements, on one side by massmedia producers: owners and employees in this sector, and on the other side by massmedia customers: audience and publicity buyers. Robert G. Picard, a well-known researcher in mass-media economy, defines "media economics" being "the way massmedia operators come to reach the desires and needs for information and entertainment of the public, announcers and society using the available resources" (Picard, 1998: 7).

We try to analyse in this section the consumption of radio services offered by the main broadcasters from Romania in 2011-2013. We will start to analyse first the Capital than the urban level in Romania.

We notice (see Table 1) that the first station arranged by audience has about 250,000 listeners, meaning approximately $10 \%$ of Bucharest population, and the one placed on $10^{\text {th }}$ place has about 50,000 , meaning $2 \%$ of the Capital population in Romania.

We can also notice the fact that we have important audience fluctuations of the operators we analysed in the period 2011-2013: we notice drops as well as growths with values over $25 \%$. This way, Radio $\mathrm{ZU}$, the most listened radio station in Bucharest, had a growth in 2012 comparative to 2011 with 64,100 listeners, and in 2013 a drop of the listeners with 45,000 comparative to 2012 . Although we have important fluctuations, the classification 
didn't change in the analysed period; it seems so that the economic operators have a close handling of the customer relationship. Operators answer regarding market demand kept the order in the radio classification from Bucharest according to audience.

Table 1: The situation of the first 10 radio stations arranged by audience in the Capital in the period 2011-2013

\begin{tabular}{|c|c|c|c|c|c|}
\hline \multirow{2}{*}{$\begin{array}{l}\text { Radio } \\
\text { Station }\end{array}$} & $\begin{array}{ll}\text { No. } & \text { of } \\
\text { listeners }\end{array}$ & $\begin{array}{l}\text { No. } \\
\text { listeners }\end{array}$ & \multirow{2}{*}{$\begin{array}{l}\text { Difference } \\
\text { 2011-2012 }\end{array}$} & $\begin{array}{l}\text { No. } \\
\text { listeners }\end{array}$ & \multirow{2}{*}{$\begin{array}{l}\text { Difference } \\
\text { 2012-2013 }\end{array}$} \\
\hline & $\begin{array}{l}\text { Fall of the } \\
\text { year } 2011\end{array}$ & $\begin{array}{l}\text { Fall of the } \\
\text { year } 2012\end{array}$ & & $\begin{array}{l}\text { Fall of the } \\
\text { year } 2013\end{array}$ & \\
\hline Radio ZU & 238,400 & 302,500 & 64,100 & 257,500 & $-45,000$ \\
\hline RRA & 222,300 & 236,200 & 13,900 & 234,200 & $-2,000$ \\
\hline Kiss FM & 222,300 & 192,200 & $-30,100$ & 181,900 & $-10,300$ \\
\hline Magic FM & 162,500 & 177,200 & 14,700 & 168,100 & $-9,100$ \\
\hline Europa FM & 108,700 & 115,100 & 6,400 & 113,800 & $-1,300$ \\
\hline Radio 21 & 88,700 & 98,700 & 10,000 & 102,900 & 4,200 \\
\hline Pro FM & 121,300 & 126,300 & 5,000 & 102,300 & $-24,000$ \\
\hline Romantic FM & 105.500 & 103,000 & $-2,500$ & 97,900 & $-5,100$ \\
\hline Rock FM & 64,200 & 81,600 & 17,400 & 88,100 & 6,500 \\
\hline Național FM & 59,600 & 40,100 & $-19,500$ & 50,900 & 10,800 \\
\hline
\end{tabular}

Source: Designed by author based on the data provided by the Society for Radio Audience (SRA) www.audienta-radio.ro

It seems that we have a pretty close competition between main competitors on radio segment from media market at the Capital level. The fact that in the first three years the main ten competitors kept their positions and market share proves that each one of the operators does whatever it takes in order to keep de business running, and it even tries to conquer more and more of the market.

At the national level, in Romania, classification of the first 10 operators by audience is different from the classification in Bucharest, although all ten operators broadcast from Bucharest and have the headquarters and main production studious there. We present in the next table the evolution of the first ten competitors from the radio segment in media market at a national level.

Table 2: The situation of first 10 radio stations ordered by audience at the national level in 2011-2013

\begin{tabular}{|l|r|r|r|r|r|}
\hline Radio Station & $\begin{array}{c}\text { Listeners no. } \\
\text { in the fall of } \\
\mathbf{2 0 1 1}\end{array}$ & $\begin{array}{c}\text { Listeners } \\
\text { no. in the } \\
\text { fall of } \mathbf{2 0 1 2}\end{array}$ & $\begin{array}{l}\text { Difference } \\
\mathbf{2 0 1 1 - 2 0 1 2}\end{array}$ & $\begin{array}{c}\text { Listeners no. } \\
\text { in the fall of } \\
\mathbf{2 0 1 3}\end{array}$ & \multicolumn{1}{|c|}{$\begin{array}{l}\text { Difference } \\
\mathbf{2 0 1 2 - 2 0 1 3}\end{array}$} \\
\hline Kiss FM & $1,714,000$ & $1,663,700$ & $-50,300$ & $1,165,600$ & $-491,000$ \\
\hline RRA & $1,231,700$ & $1,297,200$ & 65,500 & $1,280,400$ & $-16,800$ \\
\hline Radio ZU & 1.048 .100 & $1,262,400$ & 214,300 & 793,100 & $-469,000$ \\
\hline Europa FM & $1,052,400$ & $1,132,800$ & 80,400 & 682,100 & $-549,000$ \\
\hline Pro FM & 942,800 & $1,006,400$ & 63,600 & $1,073,100$ & 66,700 \\
\hline Magic FM & 567,000 & 575,400 & 8,400 & 658,500 & 83,100 \\
\hline Radio 21 & 474,200 & 509,100 & 34,900 & 516,700 & 7,600 \\
\hline Antena Satelor & 227,300 & 218,500 & 8,800 & 244,800 & 26,300 \\
\hline Rock FM & 146,300 & 205,500 & 59,200 & 206,500 & 1,000 \\
\hline National FM & 214,300 & 202,000 & $-12,300$ & 202,300 & 300 \\
\hline
\end{tabular}

Source: Designed by author based on the data provided by Society for Radio Audience (SRA), www.audienta-radio.ro 
At a national level, in the analysed period we have important fluctuations: three of the stations have lost about 500.000 listeners, changing the order of the general classification at the end of year 2013, comparative to year 2011. Radio România Actualități becomes the most listened station at a national level, although Radio Kiss FM had a considerable advance of 480.000 listeners.

If in the period 2011-2012, only the dominant position operator, Radio Kiss FM, has lost audience, in the period 2012-2013, all stations that had an audience over 1 million registered a significant drop. But the station with a smaller audience registered a constant growth, permanently raising the market share.

At the end of year 2013, none of the actors present on the radio segment of the media market have more than $7 \%$ of audience, while the $10^{\text {th }}$ passes a little over $1 \%$. We have three radios that hold about $7 \%$ of market share at a national level, we have three radios that hold about $1 \%$, and the other four, part of the analysed group hold between 2 and $5 \%$ of the market share on the radio segment at a national level.

So, at a national level we can notice a drop tendency of the operators that hold high market share and a growth of the operators that had lower market share. The technological development allowed multiple operators to raise the production quality, now, local operators having more and more share on the local media market in all localities.

We notice a tendency of a more uniform distribution of consumers, a positive element that assure favourable premises for the growth of services competition and quality offered by mass-media in the future.

We can observe from the tables at the level of media consumption on the radio segment, that the behaviour of Capital consumers is different than the national behaviour.

Actual performances, competition and competitiveness of the actors on radio market transmit an optimistic signal regarding the quality and adaptation of offered services in the future on this specific market. But the financial aspect remains a key element for continuity. We will analyse this part in the next section.

\section{Elements of economic performance of the radio sector quantified in financial results}

The development of human society is strongly connected to the economic development. Economic quality and value of media products and services determines today who remains on the market and who leaves the stage.

Audience and public image are important advantages of media industry, but for any society incomes are decisive, regarding evaluation of success as well as future orientation. Forecasting has as starting point previous results. In his famous paperwork "Understanding media", Marshall McLuhan shows how important are money in media sector. "Money talk, because money are a metaphor, a transfer and a bridge. Like words and language, money is a depository of work, compensation and experience gained in common. But money also represent a specialized technology, like writing; and just as writing intensifies the visual aspect of talking and order, and the clock visual separates time from the space, in the same way money separate work from other social functions. As a wide social metaphor, bridge or translator, money and writing as well accelerate the exchanges and strengthen the interdependence connections in any community. Money offer a wide spatial extension and control of the politic organizations, just as writing and calendar do. It is a distance action both in space and time. In an extreme literate and fragmented society, "time means money", and money is a depository of time and other people efforts." (McLuhan 2011:187) This way, for media industry, income and expenses situation represent landmarks in order to evaluate efficiency, performance, competiveness and future. 
Mass-media businesses in the modern world have been built through publicity funding. This system had success until now, and incomes gained from publicity can't be neglected, because these reflect in a big way quality and performance of mass-media operators.

Romanian Office of Transmedia Audit (Biroul Român de Audit Transmedia - BRAT) has the ability to present annually the situation of incomes gained out of publicity by economic actors in mass-media. In the publicity case, BRAT analysed publicity volumes attracted by the main eight radio stations in Romania. We present in the next figure the distribution of publicity volume attracted by each one of the eight active companies present on the Romanian publicity market.

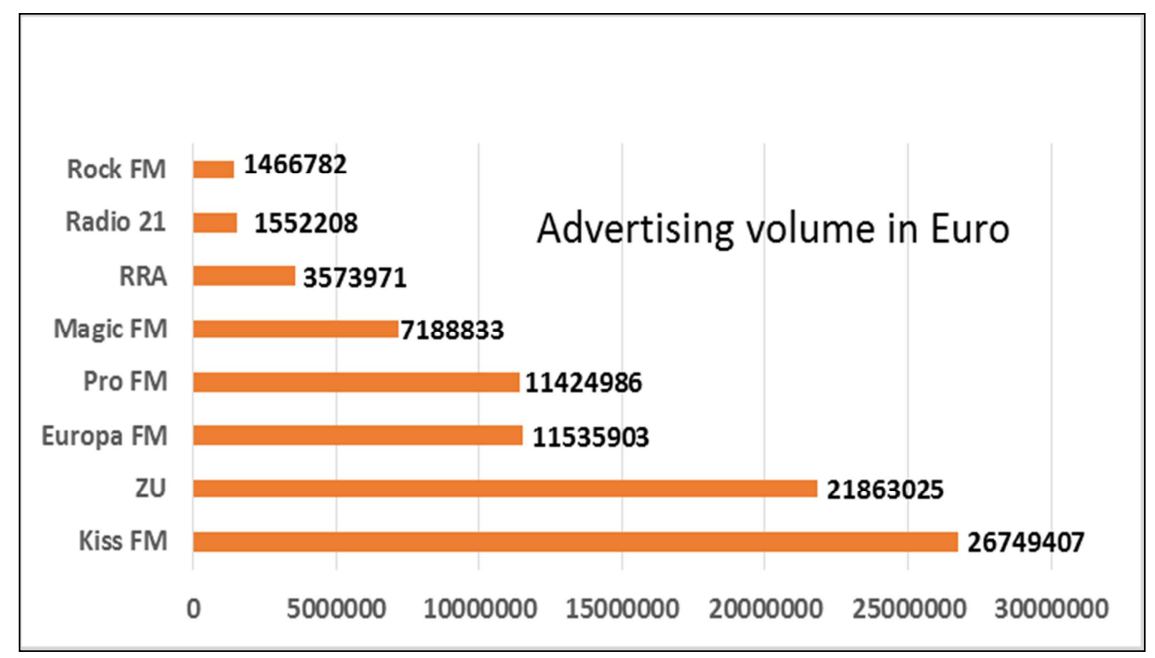

Figure 3: Distribution of publicity volume attracted by the biggest radio networks from Romania in year 2012

Source: Designed by the author based on the data provided by Romanian Office of Transmedia Audit (Biroul Român de Audit Transmedia - BRAT) http://www.brat.ro/mip/publicitatea-mip-in-2012

We can notice that radio stations that have a bigger audience managed to attract bigger incomes out of advertising, but the audience classification it is not the same with the classification of the incomes out of advertising. In our opinion, an essential role in attracting founds out of publicity has the management of the companies. The relationships they managed to build are extremely valuable. On the other hand, a major role in attracting publicity volumes has the available audience time radio stations have. For example, Radio România Actualităţi was on the second place in 2012 in the audience top but managed to be only on fourth place regarding publicity incomes.

Publicity is important, but it is not the only source of income for mass-media economic operators. We present in the next table the financial situation of economic operators from the radio sector ordered by the volume of incomes in the period 2012-2013.

Although audience of analysed radio networks remains to high levels, and the gained amounts out of publicity grew significantly in the period 2012-2013, the general economic situation operators have, it is not too optimistic in our opinion. We understand out of balance sheets that are published on the Minister of Public Finances site, that only three of the societies that exploit radio licenses had in 2012 and 2013 bigger incomes than one million euros, the others having smaller incomes. 
Table 3: Rate of turnover and profit/loss account of the main companies that operate radio licenses in Romania in the period 2012 and 2013

\begin{tabular}{|l|l|l|l|l|l|}
\hline Station & $\begin{array}{l}\text { Company that } \\
\text { operates the } \\
\text { license }\end{array}$ & $\begin{array}{l}\text { Turnover } \\
\text { rate 2012 } \\
\text { (euro) }\end{array}$ & Profit/loss 2012 & $\begin{array}{l}\text { Turnover } \\
\text { rate 2013 } \\
\text { (euro) }\end{array}$ & $\begin{array}{l}\text { Profit/ loss } \\
\mathbf{2 0 1 3}\end{array}$ \\
\hline $\begin{array}{l}\text { Radio Zu, } \\
\text { Romantic } \\
\text { FM }\end{array}$ & $\begin{array}{l}\text { Media Camina } \\
\text { Group }\end{array}$ & $5,351,993$ & 72,811 & $6,427,039$ & 99,311 \\
\hline $\begin{array}{l}\text { Europa } \\
\text { FM }\end{array}$ & $\begin{array}{l}\text { Europe } \\
\text { Development } \\
\text { International-R }\end{array}$ & $3,264,680$ & $-1,618,133$ & $4,038,139$ & 350,488 \\
\hline Radio 21 & Radio XXI SRL & 875,538 & $-1,925,005$ & $1,092,675$ & $-1,315,871$ \\
\hline Vibe FM & RFI \\
Romania & $\begin{array}{l}\text { Radio France } \\
\text { International }\end{array}$ & 698,896 & $-16,532$ & 622,945 & $-38,537$ \\
\hline ItsyBitsy & $\begin{array}{l}\text { On air studio } \\
\text { SRL }\end{array}$ & 291,478 & $-72,15$ & 235,783 & 793 \\
\hline $\begin{array}{l}\text { Sport Total } \\
\text { FM }\end{array}$ & $\begin{array}{l}\text { Global Media } \\
\text { Expert }\end{array}$ & 166,924 & 485 & 99,242 & 519 \\
\hline Rock FM & Canet Radio & 95,400 & -107 & 83,736 & $-99,784$ \\
\hline Music FM & $\begin{array}{l}\text { Campus Radio } \\
\text { SRL }\end{array}$ & 25,352 & $-36,336$ & 16,764 & $-34,575$ \\
\hline Dance FM & SR & & & & \\
\hline Source: D D & & & & & \\
\hline
\end{tabular}

Source: Designed author based on the data provided by Minister of Public Finances, http://www.mfinante.ro/pjuridice.html?pagina=domenii

To have a holistic image, we graphically present the turnover rate and profit/loss account of the main companies that operate radio licenses in Romania for year 2013.

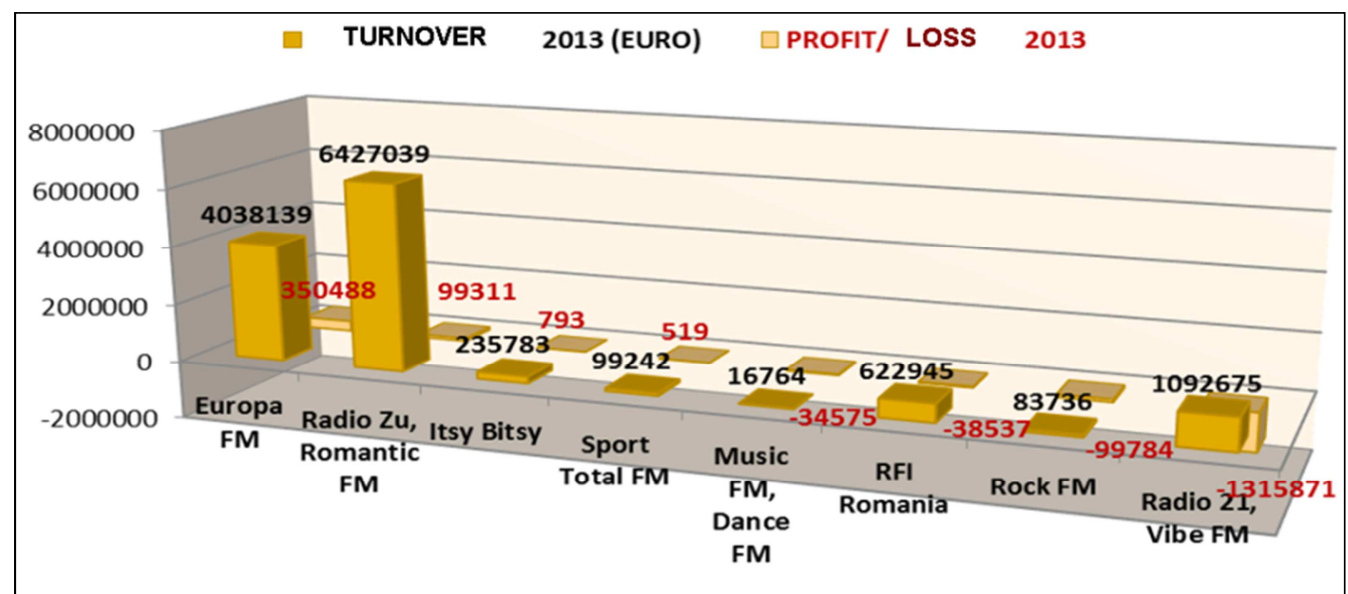

Figure 4: Turnover rate and profit/loss account of the main companies that operate radio licenses in Romania in 2013

Source: Designed by the author based on the data provided by Minister of Public Finances, http://www.mfinante.ro/pjuridice.html?pagina=domenii

Financial situation of the companies that operate on mass-media market on radio segment is less encouraging than the situation of audience radio stations have.

Media Camina Group, that holds the licenses of the stations Radio Zu and Romantic FM, obtained the biggest incomes, both in 2012 and 2013. Also, Media Camina Group has the 
biggest expenses as well as a constant profit: 72 thousand euros in 2012 and 99 thousand euros in 2013.

International-R Europe Development Society, that holds national audio-visual license for radio Europa FM, had in 2012 significant losses: 1.6 Million euros, but in 2013 had a very good recovery, obtaining a 350 thousand euros profit.

The most unfavourable situation is recorded by the Society Radio XXI SRL, that exploits two licenses, one for Radio 21 network and the second for Radio Vibe FM; so during year 2012 it recorded losses of almost 2 million euros, while incomes didn't step up even half to that; in 2013 it recorded losses of 1.3 million euros, which is bigger than the income, that raised a bit over 1 million euros.

The licenses for Kiss FM and Magic FM stations that are first in the audience rank are hold by SBS Broadcasting, and ProFM is part of ProTV SA group, companies that exploit TV licenses as well.

\section{Conclusions}

Shortly after the telegraph appeared, radio made its place bringing the voice from a great distance into the intimacy of homes. Radio doesn't only eliminate the distances but also transmits the message with a special force, speed and accuracy. We can easily notice that radio became a very strong communication vector in the world. The interest towards programs and the power of influence have been intuited and exploited by the programs producers as well as by politicians. Because radio was managed by professionals, just as Marshall McLuhan shows - "telegraph and radio neutralized nationalism, but evoked the tribal archaic ghosts in the most powerful way. This means the reunion of sight and hearing, of explosion with implosion or, as Joyce said it in "Finnegan's Wake”, "the end meets with industry" (McLuhan, 2011: 389). We notice here the cultural role radio took and amplified. In the same time, the economic reality of radio segment in mass-media sector reveals a polarized distribution of the incomes and an economic situation in line for the most companies that operate radio licenses. It seems that the economic situation it is not favourable and the companies will be forced in the next period to make actions in order to recover the balance of incomes and expenses. Surely it raises the question: in which way the measures taken for the economic growth will affect quality, performance and the ability to attract audience? The answer is not that simple and surely it can't be generalized; but as long as audience maintains to high levels, in our opinion the recover economic measures that are taken are imperative and can be successful.

\section{Acknowledgements}

The present paper is part of the research done for preparing the doctorate thesis: "Innovation and transformation in media industry“, developed within the Doctoral School of Economics, University of Oradea, under the supervision of Prof. Dr. Alina Bădulescu.

\section{References}

Juran, J.M. (2011). Articole realizate de Joseph Moses Juran - Antologie / Articles written by JM Juran - Anthology, Editura Proxima, Bucureşti.

McLuhan, M. (2011). Să înţelegem media: Extensiile omului / Understanding Media The extensions of man, Bucuresti: Editura Curtea Veche.

Picard, G. R. (1989). Media Economics: Concepts and Issues, Newbury Park, London, New Delhi: Sage.

Biroul Român de Audit Transmedia / Romanian Audit Office Transmedia (BRAT) [Online]. Available: http://www.brat.ro/mip/publicitatea-mip-in-2012,[14 Feb 2016]. 
Ministerul Finanţelor Publice / Minister of Public Finances [Online]. Available: http://www.mfinante.ro/pjuridice.html?pagina=domenii, [10 Dec 2015].

Asociația pentru Radio Audienţă / Association for Radio Audience (ARA) [Online]. Available: www.audienta-radio.ro, [10 Feb 2016].

Media Factbook [Online]. Available: www.mediafactbook.ro/, [10 Feb 2016].

\section{Bio-note}

Daniel Burtic has a MA in communication, MA in management and a Ph.D. in economics. He worked 20 years in the media industry, held a wide range of positions: operator, editor, editorial secretary, chief producer, and since 2001 he is director of a company operating in the media industry. His research areas include: the economics of media industry, creative economy, digital communication, innovation in media, quality and performance in the media industry, legislation for journalists and management of media institutions in the digital age. 